\title{
STRATEGI PEMASARAN BANK SYARIAH MANDIRI DALAM MENINGKATKAN PENJUALAN PRODUK PENSIUN
}

\author{
Iskandar Ritonga ${ }^{1}$, Eka Purwati ${ }^{2}$ \\ UIN Sunan Ampel Surabaya ${ }^{1}$, Institut Agama Islam Darussalam Blokagung \\ Banyuwangi ${ }^{2}$ \\ Email: iskandaritonga@gmail.com¹, ekaw56177@gmail.com²
}

\begin{abstract}
This study aims to (1) Determine the marketing strategy of Bank Syariah Mandiri in increasing sales of pension products, (2) The strengths and weaknesses of the marketing strategy of Bank Syariah Mandiri in increasing product sales. The result of this research is that the marketing strategy is the marketing activities carried out by the Bank's management in order to achieve the marketing target. This marketing Strategy is structured based on what should be done, who does, and when to do it. The marketing strategy used by Bank Syariah Mandiri in increasing sales of pension products is by using an approach and promotion strategy. This approach to customers can enhance Bank Syariah Mandiri's long-term growth and maximum customer satisfaction. After carrying out the approach process, the next stage is the promotion strategy. Promotion is an activity that aims to convey information about pension products to customers, so that the pension product is known and can encourage customers to use it. Promotion is also very useful for providing information about the advantages or disadvantages of these retirement products.
\end{abstract}

\section{Keywords: Marketing Strategy, Sharia Marketing, Islamic Bank}

\begin{abstract}
Abstrak
Penelitian ini bertujuan untuk (1) Mengetahui strategi pemasaran Bank Syariah Mandiri dalam meningkatkan penjualan produk pensiun, (2) Kekuatan dan kelemahan dari strategi pemasaran Bank Syariah Mandiri dalam meningkatkan penjualan produk. Hasil penelitian ini adalah strategi pemasaran adalah kegiatan pemasaran yang dilakukan manajemen Bank agar target pemasaran tercapai. Strategi pemasaran ini disusun berdasarkan apa yang harus dilakukan, siapa yang melakukan, dan kapan dilakukan. Strategi Pemasaran yang digunakan Bank Syariah Mandiri dalam meningkatkan penjualan produk pensiun yaitu menggunakan strategi pendekatan dan promosi. Pendekatan pada nasabah dapat meningkatkan pertumbuhan jangka panjang Bank Syariah Mandiri dan kepuasan maksimum pelanggan. Setelah melakukan proses pendekatan masuk pada tahap selanjutnya yaitu strategi promosi. Promosi yaitu kegiatan yang bertujuan untuk menyampaikan informasi mengenai produk pensiun kepada nasabah, sehingga produk pensiun tersebut dikenal dan dapat mendorong para nasabah untuk menggunakannya. Promosi juga sangat berguna untuk memberikan informasi mengenai kelebihan atau keunggulan dari produk pensiun tersebut.
\end{abstract}

\section{Kata Kunci: Strategi Pemasaran, Marketing Syariah, Bank Syariah}


Jurnal Ekonomi Syariah Darussalam

Vol I No I Agustus 2020, ISSN: 2745-8407

\section{A. PENDAHULUAN}

Strategi pemasaran adalah sebuah rencana yang menjelaskan ekspektasi Bank Syariah mengenai dampak dari berbagai kegiatan dan program pemasaran terhadap permintaan produk. Bank Syariah bisa menggunakan beberapa program strategi pemasaran secara bersamaan, karena setiap jenis program pemasaran seperti pendekatan kepada nasabah, promosi penjualan, penjualan perorangan/personal selling dan layanan pelanggan mempunyai pengaruh yang masing-masing berbedabeda terhadap permintaan. Strategi ini dilakukan agar masyarakat berminat untuk mengambil manfaat dari produk-produk yang ditawarkan sesuai dengan kebutuhan mereka. Istilah strategi pemasaran menurut Kotler yaitu suatu proses sosial dan manajerial yang mana individu dan kelompok mendapatkan apa yang mereka butuhkan melalui penciptaan dan pertukaran produk nilai satu sama lain. Menurut American Marketing Association 2007 pemasaran merupakan serangkaian aktivitas dan proses untuk menyampaikan atau mempromosikan produk dan melakukan pendekatan terhadap nasabah lama maupun calon nasabah baru (Lidyasari, 2018:38).

Definisi ini menunujukkan bahwa strategi seharusnya menjelaskan unsur apa yang harus dicapai oleh bank, kemana usaha serta produknya akan fokus dan yang terakhir unsur bagaimana sumber daya dialokasikan untuk memenuhi peluang dan tantangan lingkungan serta meraih keunggulan kompetitif. Maka strategi dapat diartikan sebagai suatu rencana yang disusun oleh manajemen puncak untuk mencapai tujuan yang diinginkan. Rencana ini meliputi tujuan dan kebijakan yang harus dilakukan oleh suatu organisai dalam mempertahankan eksistensi dan memenangkan persaingan, terutama perusahaan atau organisasi harus memiliki keunggulan kompetitif (Wicaksono, 2017:12).

Strategi pemasaran menurut MA. Mannan didalam bukunya Ekonomi Islam yang berjudul Teori dan Praktek menjelaskan bahwa Islam telah memberikan suatu rencana yang dapat diwujudkan melalui bimbingan perencanaan melainkan memanfaatkan karunia Allah secara sistematik agar dapat mencapai tujuan tertentu, dengan memperlihatkan kebutuhan masyarakat dan nilai kehidupan yang berubahubah, perencanaan menyangkut tentang adanya persiapan untuk menyusun rancangan di setiap kegiatan ekonomi. Konsep tentang perencanaan yang harus 
Jurnal Ekonomi Syariah Darussalam

Vol I No I Agustus 2020, ISSN: 2745-8407

dipahami, telah diakui dalam Islam. Karena perencanaan ini mencakup pemanfaatan sumber yang telah disediakan oleh Allah SWT dengan sebaikbaiknya untuk kehidupan dan kesenangan manusia (Marhari, 2012:46).

Penentuan strategi pemasaran harus didasarkan atas analisis lingkungan dan internal perusahaan melalui analisis keunggulan dan kelemahan perusahaan, serta analisis kesempatan dan ancaman yang dihadapi perusahaan dari lingkungannya. Disamping itu strategi pemasaran yang telah ditetapkan dan dijalankan, harus dinilai kembali, apakah masih sesuai dengan kondisi atau keadaan pada saat itu. Hasil penilaian atau evaluasi ini digunakan sebagai dasar untuk menentukan apakah strategi yang sedang dijalankan perlu diubah, sekaligus digunakan sebagai landasan untuk menyusun atau menentukan strategi yang akan dijalankan dimasa yang akan datang (Abdhad, 2019:14). Dari latar belakang tersebut maka rumusan masalah yang dibuat peneliti adalah: 1) Bagaimana strategi pemasaran Bank Syariah Mandiri dalam meningkatkan penjualan produk pensiun?, 2) Bagaimana kekuatan dan kelemahan dari strategi pemasaran Bank Syariah Mandiri dalam meningkatkan penjualan produk pensiun?

\section{B. LANDASAN TEORI}

\section{Strategi Pemasaran}

Menurut Philip Kotler strategi pemasaran merupakan suatu kegiatan pemasaran yang digunakan untuk mencapai tujuan pemasaran di masa yang akan datang. Strategi pemasaran (marketing strategy) adalah prinsip yang menyeluruh dimana manajemen pemasaran mengharapkan untuk dapat mencapai semua tujuan pemasaran danbisnis dalam pasar sasaran. Dalam merumuskan strategi pemasaran dari suatu perusahaan tidak dapat dilepaskan dari strategi perusahaan atau unit bisnisnya. Strategi pemasaran pada dasarnya merupakan rencana yang terpadu, menyeluruh dan menyatu di bidang pemasaran,yang memberikan pedoman tentang kegiatan-kegiatan yang akan dijalankan agar dapat tercapainya suatu tujuan pemasaran perusahaan (Arifah, 2018:23). Strategi pemasaran telah banyak dikembangkan, baik melalui manajemen science (Pengembangan Teknologi) untuk membantu pengambilan keputusan atau pengembangan toeri manajemen strategis yang lebih di update sesuai dengan perkembangan kondisi politik, ekonomi soaial, budaya yang terjadi secara global. Begitu banyaknya contoh strategi, akan tetapi 
Jurnal Ekonomi Syariah Darussalam

Vol I No I Agustus 2020, ISSN: 2745-8407

setiap perusahaan tidak begitu saja mengadopsi penuh strategi yang dipilih, tanpa mempertimbangkan kondisi rill (nyata) dari perusahaan yang bersangkutan. Itu berarti penyesuaian strategi harus mempertimbangkan dari pengembangan misi tujuan perusahaan (Sabariah, 2016:105).

Setelah mengetahui sasaran penjualan yang akan dituju hendaknya kita harus mengukur dan mengetahui kemampuan dan kelemahan yang dimiliki bank syariah dalam menangkap peluang dan meminimalisir ancaman melalui analisa SWOT untuk menentukan strategi yang baik dan tepat dalam mencapai sebuah tujuan (Muhammad, 2011:231). SWOT adalah singkatan dari kata strengths, weakness, opportunities dan threats yang berarti kekuatan, kelemahan, peluang, dan ancaman. Analisis SWOT merupakan teori yang digunakan untuk merencanakan sesuatu berdasarkan kekuatan, kelemahan, kesempatan, dan ancaman. Analisis SWOT bisa juga berarti sebuah metode perencanaan yang berdasarkan pada penilaian kekuatan, kelemahan, kesempatan dan ancaman yang terlibat di dalam suatu proyek atau suatu usaha. Hal ini tentu saja melibatkan tujuan usaha beserta identifikasi faktor internal dan eksternal yang akan menguntungkan bagi pencapaian tujuan usaha tersebut (Anggen, 2012:96).

\section{Marketing Syariah}

Konsep marketing syariah sebenarnya tidak jauh berbeda dengan marketing yang kita kenal, perbedaannya dalam syariah mengajarkan pelakunya bersikap jujur kepada konsumen. Sebagaimana yang telah dijelaskan dalam Al Qur'an surat AnNisa ayat 29 yang berbunyi :

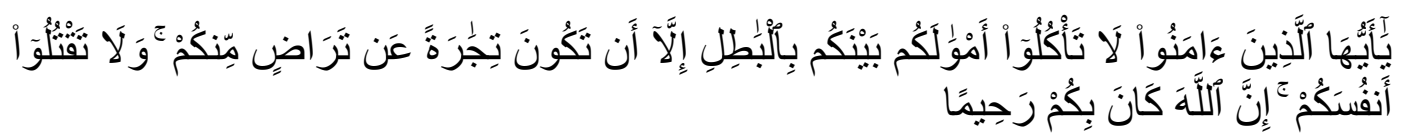

Artinya :"Hai orang-orang yang beriman, janganlah kamu saling memakan harta sesamamu dengan jalan yang batil, kecuali dengan jalan perniagaan yang berlaku dengan suka sama-suka di antara kamu. Dan janganlah kamu membunuh dirimu; sesungguhnya Allah adalah Maha Penyayang kepadamu” (Al Qur'an surat An-Nisa ayat 29).

Ayat di atas menjelasakan tentang keharaman orang beriman memakan, memanfaatkan dan menggunakan harta orang lain dengan jalan batil yaitu jalan yang tidak dibenarkan oleh syariat. Dalam ayat ini menjelaskan bahwa orang-orang mukmin hanya diperbolehkan melakukan transaksi terhadap harta orang lain dengan saling ikhlas dan saling ridho. Menurut Hermawan Kartajaya menuturkan 
Jurnal Ekonomi Syariah Darussalam

Vol I No I Agustus 2020, ISSN: 2745-8407

bahwa ada beberapa konsep dalam pemasaran syariah diantaranya (Muhammad Syakirsula, 2006:9):

1. Syariah Marketing Strategy; Dengan menggunakan konsep ini, pemasar dapat memetakan pasar berdasarkan ukuran pasar, pertumbuhan pasar, keunggulan pasar serta situasi persaingan.

2. Syariah Marketing Tactic; Setelah menentukan starategi pemasaran, berikutnya melakukan Marketing Tactic. Marketing ini digunakan untuk memenangkan market share.

3. Syariah Marketing Value; Setelah menentukan strategi dan menjalankan taktik, selanjutkan menerapkan diferensiasi kreatif dan inovatif dengan menerapkan teknik marketing mix yaitu price, product, place, promotion.

4. Syariah Marketing Storecard; Marketing storecard digunakan untuk menjaga keseimbangan value yang unggul kepada para stakeholder dengan bobot dan ukuran yang sama.

5. Syariah Marketing Enterprise; Marketing enterprise digunakan untuk menciptakan sebuah inspirasi. Inspirasi disini sama halnya dengan impian. Setiap perusahaan wajib hukumnya untuk memiliki impian, karena dengan impian mampu membimbing perusahaan selama perjalanannya. Sejatinya konsep pemasaran mempunyai perspektif dari luar ke dalam. Titik awal dari konsep pemasaran adalah mengetahui konsumen, siapa dia?, apa yang dia butuhkan? kemudian memikirkan bagaimana cara memenuhi kebutuhannya guna menciptakan rasa puas dalam waktu yang panjang yang kemudian memungkinkan konsumen melakukan pembelian ulang.

\section{Bank Syariah}

Bank Syariah merupakan bank yang secara operasional berbeda dengan Bank Konvensional. Salah satu ciri khas Bank Syariah yaitu tidak menerima dan tidak membebani bunga kepada nasabahnya, akan tetapi menerima atau membebankan bagi hasil serta imbalan lain sesuai dengan akad-akad yang telah diperjanjikan. Semua jenis produk dan jasa yang ditawarkan kepda nasabah tidak boleh bertentangan dengan isi Al-Qur'an dan Hadist Rasulullah SAW (Ismail, 2011:30).

Setiap Bank Syariah mempunyai tujuan untuk dapat tetap hidup dan berkembang, tujuan tersebut hanya dapat dicapai melalui usaha mempertahankan 
Jurnal Ekonomi Syariah Darussalam

Vol I No I Agustus 2020, ISSN: 2745-8407

dan meningkatkan tingkat keuntungan/laba bank. Usaha hanya dapat bertahan apabila bank dapat mempertahankan dan meningkatkan penjualannya melalui usaha mencari dan membina langganan, serta usaha menarik perhatian para calon nasabah. Tujuan ini hanya dapat dicapai apabila para marketing melakukan strategi yang mantap untuk dapat menggunakan kesempatan atau peluang yang ada dalam pemasaran, sehingga posisi dan kedudukan Bank Syariah di masyarakat dapat dipertahankan dan sekaligus ditingkatkan (Assauri, 2010:167-168).

\section{Penelitian Terdahulu yang Relevan}

Dwi Pratiwi (2018) "Strategi Pemasaran Produk Tabungan Haji iB Makbul Dipt. Bank Sumut Cabang Syariah Medan”. Peneliti menggunakan metode kualitatif, dari penelitian ini diperoleh kesimpulan bahwa Dalam memasarkan produk tabungan Haji iB Makbul PT. Bank Sumut cabang Syariah menggunakan sistem marketing mix yang menunjukkan bahwa produk, harga, promosi, dan tempat sangat berpengaruh terhadap proses pemasaran. Yang mana dengan menggunakan perumusan startegi pemasaran tersebut bertujuan untuk menarik dan memepertahankan loyalitas nasabah. Perbedaan dengan penelitian ini terletak pada alat analisisnya yaitu deskriptif kualitatif, sedangkan yang peneliti gunakan adalah alat analisis SWOT, sedangkan persamaan dengan penelitian ini terletak pada strategi pemasarannya dan objek penelitian terletak di Bank Syariah.

M kahfi Al Abdhad (2019) “Analisis Strategi Pemasaran Pada BRI Syariah Banjarbaru". Penelitian ini menggunakan metode penelitian deskriptif kuantitatif, dari peneliti ini diperoleh kesimpulan bahwa strategi pemasaran pada Bank Rakyat Indonesia Syariah Cabang Banjarbaru selama ini menerapkan strategi pemasaran 4P, yaitu (1) Produk memiliki karakteristik penghimpunan dana dan pembiayaan, (2) Price, untuk uang administrasi perbulan di Bank Rakyat Indonesia Syariah Cabang Banjarbaru lebih rendah dibandingkan dengan bank lainnya, baik yang syariah apalagi konvensional, (3) Promosion, promosi yang dijalankan melalui cara periklanan (brosur, spanduk, dan surat kabar lokal/daerah), (4) Place, tempat mudah dijangkau masyarakat dengan kendaraan umum, berada di pusat atau jantungnya Kota Banjarbaru. Perbedaan dengan penelitian ini terletak pada objek dari penelitian ini ialah strategi pemasaran pada BRI Syariah dan jenis penelitian yang 
Jurnal Ekonomi Syariah Darussalam

Vol I No I Agustus 2020, ISSN: 2745-8407

digunakan ialah kuantitatif, sedangkan persamaannya yaitu sama-sama menggunakan analisis SWOT.

\section{METODE PENELITIAN}

\section{Jenis Penelitian}

Dalam penelitian kualitatif ini, peneliti menggunakan pendekatan lapangan yaitu penelitian yang objeknya mengenai gejala-gejala atau peristiwa-peristiwa yang terjadi pada tempat penelitian. Yaitu penelitian mengenai peristiwa-peristiwa yang terjadi di Bank Syariah Mandiri KC Genteng. Penelitian ini bisa disebut penelitian studi kasus dengan pendekatan deskriptif kualitatif yaitu dengan cara menguraikan data-data yang diperoleh, selanjutnya data-data tersebut dianalisis.

\section{Lokasi dan Waktu Penelitian}

Tempat Bank Syariah Mandiri Kc Genteng yang berlokasi di Jln. Gajah Mada Nomor. 159 Genteng Kulon, Kabupaten Banyuwangi, Provinsi Jawa Timur. Waktu pelaksanaan penelitian di mulai pada bulan Maret - Agustus 2019.

\section{Sumber Data}

Dilihat dari sumber datanya, pengumpulan data dapat menggunakan sumber data primer dan sumber data sekunder dalam penelitian ini adalah sebagai berikut:

1. Sumber data primer dalam penelitian ini adalah data utama yang diperoleh secara langsung dari lapangan. Data primer ini diperoleh dari wawancara dengan pihak-pihak Bank yang terkait seperti RBRM (Retail Banking Relationship Manajer), KASF (Kordinator Area Sales Force), SF(Sales Force), SF (Sales Force).

2. Sumber data sekunder dalam penelitian ini yaitu melalui orang lain, bukubuku, data-data, dan arsip-arsip yang memiliki keterkaitan masalah tentang strategi pemasaran Bank Syariah Mandiri.

\section{Teknik Pengumpulan Data}

Teknik pengumpulan data adalah suatu cara atau proses yang sistematis dalam pengumpulan, pencatatan dan penyajian fakta untuk tujuan tertentu. Penelitian ini akan menggunakan dua jenis teknik pengumpulan data. Kedua teknik pengumpulan data tersebut yaitu: observasi, wawancara dan dokumentasi. 
Jurnal Ekonomi Syariah Darussalam

Vol I No I Agustus 2020, ISSN: 2745-8407

\section{Alat Analisis Data}

Teknik analisis data yang digunakan dalam penelitian ini adalah secara deskriptif dengan pendekatan analisis SWOT. SWOT adalah singkatan dari katakata Strength (kekuatan) Weaknesses (kelemahan), Opportunities (peluang) dan Threats (ancaman). Analisis SWOT digunakan untuk merumuskan strategi pemasaran berdasarkan kekuatan, kelemahan, peluang dan ancaman Bank Mandiri Syariah KC Genteng. Tahap analisis dilakukan dengan membuat matrik IFAS (internal factors analisys summary) dan matrik EFAS (eksternal factors analisys summary). Matrik IFAS disusunberdasarkan kekuatan dan kelemahan yang dimiliki oleh Bank Syariah Mandiri KC Genteng, sedangkan matrik EFAS disusun berdasarkan peluang dan ancaman yang dihadapi oleh Bank Syariah Mandiri KC Genteng. Setelah diketahui nilai dari matrik IFAS dan EFAS, maka tahap selanjutnya adalah melihat posisi perusahaan berdasarkan nilai matrik IFAS dan EFAS pada matrik IE (Internal Eksternal) yang digunakan untuk menentukan strategi pemasaran yang dapat digunakan oleh perusahaan. Sebuah penelitian yang menunjukan bahwa strategi pemasaran perusahaan dapatditentukan oleh kombinasi faktor internal dan eksternal. Kedua faktor tersebut harus dipertimbangkan dalam analisis SWOT (Abdhad, 2019:18).

\section{HASIL PENELITIAN DAN PEMBAHASAN}

Bank Syariah Mandiri adalah bank yang menjalankan usahanya berdasarkan pada prinsip-prinsip syariah Islam. Bank Syariah sering disebut Bank Islam yaitu bank yang cara beroperasinya tidak mengandalkan bunga. Bank Syariah Mandiri memiliki banyak sekali produk pembiayaan yang di keluarkannya, seperti:

1. Pembiayaan pensiun

2. Pembiayaan mikro

3. Pembiayaan otto

4. Pembiayaan griya

5. Pembiayaan implan

6. Pembiayaan cicil emas

Bank Syariah Mandiri memiliki masa dalam meningkatkan produknya. Untuk saat ini produk Pensiunan merupakan produk yang ingin lebih di tingkatkan oleh pihak Bank. Karena produk pensiunan ini memiliki tingkat risiko yang begitu kecil. 
Jurnal Ekonomi Syariah Darussalam

Vol I No I Agustus 2020, ISSN: 2745-8407

Produk ini tercipta dari melihatnya kebutuhan para nasabah, namun walau produk sudah sesuai dengan keinginan yang di butuhkan nasabah, belum tentu nasabah mengambil produk tersebut, untuk itu pihak Bank perlu menggunakan strategi yang tepat sehingga bank bisa meningkatkan produknya, terutama dalam produk pensiunan, tetap stabil dalam pengoperasiannya. Strategi Pemasaran Bank merupakan kegiatan pemasaran yang dilakukan manajamen bank agar target pemasaran tercapai. Rencana pemasaran ini disusun berdasarkan apa yang harus dilakukan, siapa yang melakukan dan kapan dilakukan.

Menurut salah satu marketing yang bekerja di Bank Syariah Mandiri KC Genteng, bahwa strategi di Bank Syariah Mandiri menggunakan berbagai macam strategi diantaranya, ungkap oleh Bapak Yusron Fauzi selaku KASF (Kordinator Area Sales Force) pada tanggal 03 Juli 2019.

"Kalau yang efektif itu menggunakan strategi pendekatan atau door to door yaitu melakukan kunjungan ke rumah nasabah seperti: Dinas Kesehatan, Dinas Pendidikan, UPTD (Dinas Pendidikan), sekolah-sekolah dan Dinas Perairan. Dan yang kedua menggunakan strategi promosi yaitu menjual produk yang ditawarkan, mengenai keunggulan-keunggulan produk pensiun tersebut”.

Tujuan Bank Syariah Mandiri melakukan Pembiayaan pensiun ungkap Bapak Puguh Hermawan selaku SF (Sales Force) pada tanggal 15 Juli 2019.

"Alasan Bank Syariah mandiri melakukan pembiayaan pensiun yaitu karena untuk saat ini perekonomian di indonesia dalam keadaan kurang stabil dan untuk pembiayaan mikro di Bank Syariah Mandiri lagi gak stabil maka di larikan ke pembiayaan pensiun untuk meminimalis adanya risiko".

Adapun Kerugian-kerugian yang pernah di alami oleh pihak Bank Syariah Mandiri ungkap Bapak Tri Wahyudi selaku RBRM.

"Kerugian-kerugian yang pernah di alami oleh pihak Bank Syariah Mandiri yaitu: 1) Sumber pembayaran pensiun itu dari gaji pensiunan, nah proses mutasi pensiun itu di Bank A ke Bank Syariah Mandiri itu taspennya butuh waktu 2 bulan. Selama 2 bulan gaji masih di bank sebelumnya, misalkan disetujui bulan juli jadi yang bersangkutan walaupun sudah di proses mutasi di Bank Syariah Mandiri yang bersangkutan bulan Agustus-September masih di Bank sebelumnya, nanti setelah tiba bulan oktober baru sudah boleh pindah ke Bank Syariah Mandiri. Dan selama proses mutasi itu 2 bulan itu ada namanya cadangan $2 x$ angsuran. Jadi yang bersangkutan selama proses tidak perlu membayar angsuran kerena sudah ada cadangan. Jika pihak Bank Syariah terlambat mengurus mutasi akhirnya cadangan disalah gunakan oleh nasabah. Misalkan lebih dari 2 bulan sudah habis dan gaji sebelumnya belum pindah ke Bank Syariah Mandiri, nah disinilah letak kerugiannya, ternyata di Bank sebelumnya diambil oleh nasabah untuk keperluan dirinya atau mungkin nasabah nakal dan lain sebagainya, maka harus di stop 
Jurnal Ekonomi Syariah Darussalam

Vol I No I Agustus 2020, ISSN: 2745-8407

karena sudah termasuk kerugian pada pihak Bank Syariah Mandiri, karena nasabah tidak menyetorkan ke Bank Syariah Mandiri. 2) Harus kuat di verifikasi dan keaslian SK pensiun. Di zaman sekarang ini banyak adanya pemalsuan, salah satunya yaitu pemalsuan SK pensiun. Nah karena SK pensiun yang jiplak/palsu sangat banyak, jadi jika Bank tidak kuat di verifikasi SK pensiun dalam proses membedakan antara mana SK yang asli dan mana yang palsu”.

Rata-rata pembiayaan pensiun di Bank Syariah KC Genteng ungkap Bapak Wawan Setiawan.

"Umumnya pembiayaan pensiun kurang lebih 150 juta, minimal pembiayaan pensiun 10 juta, dan maksimal pembiayaan pensiun 350 juta”.

Berikut peneliti menguraikan kekuatan, kelemahan, ancaman dan peluang menggunakan analisis SWOT.

1. Kekuatan dari strategi pemasaran bank syariah mandiri KC Genteng adalah kualitas produk yang ditawarkan baik, orientasinya lebih murah dibanding Bank Kompetitor, dilihat dari bagi hasi atau bunganya lebih murah (Bunganya efektif $25 \%$, rata $0,6 \%$, dan pertahunnya $12,5 \%$ ).

2. Kelemahan strategi pemasaran Bank Syariah Mandiri yaitu jarak antara nasabah A dan nasabah B saling berjauhan kalah saing dengan kualitas produk Bank lain.

3. Peluang strategi pemasaran Bank Syariah Mandiri yaitu variasi produk yang semakin menarik, memaksimalkan pemasaran, hubungan yang baik dengan nasabah.

4. Ancaman strategi pemasarn bagi para marketing pensiun di Bank Syariah Mandiri yaiitu tingkat persaingan antar Bank, bisnis pensiun adalah semakin banyak kompetitor baru, pemahaman nasabah yang kurang mengenai konsep syariah.

Rencana strategi pemasaran dapat memberikan pedoman atau panduan agar kegiatan pemasaran yang dilakukan perusahaan dapat lebih terarah dan teratur hal ini karena rencana tersebut bersifat kesatuan, menyeluruh, dan terpadu, yang mengaitkan kekuatan atau keunggulan pemasaran perusahaan dan tantangan lingkungannya. Proses strategi terdiri dari tiga tahapan (Anshori, 2014:14).

1. Perumusan Strategi

Dalam perumusan strategi termasuk didalamnya ialah mengembangkan visi dan misi perusahaan, mengidentifikasi peluang dan ancaman eksternal perusahaan, 
Jurnal Ekonomi Syariah Darussalam

Vol I No I Agustus 2020, ISSN: 2745-8407

menentukan kekuatan dan kelemahan internal perusahaan, menetapkan tujuan jangka panjang perusahaan, membuat sejumlah strategi alternatif untuk perusahaan, dan memilih strategi tertentu untuk perusahaan.

2. Pelaksanaan Strategi

Pelaksanaan strategi mengharuskan perusahaan untuk menetapkan sasaran tahunan, membuat kebijakan, memotivasi karyawan, dan mengalokasikan sumber daya sehingga perumusan strategi dapat dilaksanakan. Penciptaan struktur organisasi perusahaan yang efektif, pengembangan dan pemanfaatan sistem informasi, serta menghubungkan kompensasi untuk para marketing dengan kinerja organisasi perusahaan.

3. Evaluasi Perusahaan

Evaluasi strategi adalah tahap terakhir dalam manajemen strategis. Para manajer harus benar-benar mengetahui alasan strategi-strategi tertentu tidak dapat dilaksanakan dengan baik. Dalam hal ini, evaluasi strategi adalah cara pertama untuk memperoleh informasi.

Dalam rangka mencapai tujuan organisasi maka diperlukan suatu penguasaan informasi tentang berbagai masalah, baik di lingkungan internal maupun eksternal yang lazim dikenal dengan analisis SWOT. Analisis SWOT digunakan untuk merumuskan strategi pemasaran berdasarkan kekuatan, kelemahan, peluang dan ancaman Bank Syariah Mandiri KC Genteng. Tahap analisis dilakukan dengan membuat matrik IFAS (Internal Factors Analisys Summary) dan matrik EFAS (Eksternal Factors Analisys Summary). Matrik IFAS disusun berdasarkan kekuatan dan kelemahan yang dimiliki oleh Bank Syariah Mandiri KC Genteng, sedangkan matrik EFAS disusun berdasarkan peluang dan ancaman yang dihadapi oleh Bank Syariah Mandiri KC Genteng.

Analisis SWOT meliputi Analisis Lingkungan Internal dan Analisis Lingkungan Eksternal yaitu sebagai berikut:

1. Analisis Lingkungan Internal

a. Strength (Kekuatan), merupakan situasi dan kemampuan internal yang bersifat positif yang memungkinkan organisasi memiliki keuntungan strategis dalam mencapai tujuannya. 
Jurnal Ekonomi Syariah Darussalam

Vol I No I Agustus 2020, ISSN: 2745-8407

b. Weakness (Kelemahan), merupakan situasi dan ketidakmampuan internal yang mengakibatkan organisasi tidak dapat mencapai tujuannya atau sebagai kondisi yang menempatkan organisasi pada ketidakberuntungan dan tidak kompetitif.

2. Analisis Lingkungan Eksternal

a. Opportunities (Peluang), adalah situasi dan faktor-faktor eksternal yang membantu organisasi dalam mencapai atau bahkan melampaui pencapaian sasarannya;

b. Threat (Tantangan), adalah faktor-faktor eksternal yang menyebabkan organisasi tidak dapat mencapai sasarannya. Berdasarkan pengertian diatas maka dapat dinyatakan bahwa strategi dalam organisasi adalah serangkaian langkah yang ditempuh organisasi dengan melaksanakan analisis SWOT.

Tabel 1. Matrik SWOT

\begin{tabular}{|c|c|c|}
\hline IF & Strenghts & \\
\hline EFAS & $\begin{array}{l}\text { Kualitas produk yang } \\
\text { ditawarkan baik } \\
\text { Bank Syariah mandiri } \\
\text { orientasinya lebih murah } \\
\text { dibanding Bank } \\
\text { Kompetitor } \\
\text { Dilihat dari bagi hasil atau } \\
\text { bunganya lebih murah } \\
\text { (Bunganya efektif } 25 \% \text {, } \\
\text { rata } 0,6 \% \text {, dan } 12,5 \% \\
\text { pertahunnya) }\end{array}$ & $\begin{array}{l}\text { Jarak antara nasabah A } \\
\text { dan nasabah B saling } \\
\text { berjauhan } \\
\text { Kalah saing dengan } \\
\text { kualitas produk Bank } \\
\text { lain }\end{array}$ \\
\hline \begin{tabular}{l}
\multicolumn{3}{|c}{ Opportunities } \\
Persaingan antar Bank \\
Variasi produk yang \\
semakin banyak dan \\
menarik \\
$>\begin{array}{l}\text { Hubungan yang baik } \\
\text { dengan nasabah }\end{array}$ \\
- Kemajuan teknologi yang \\
semakin canggih
\end{tabular} & \begin{aligned} & \multicolumn{1}{c}{ Strategi SO } \\
& Meningkatkan \\
& pengembangan produk \\
& Meningkatkan pelayanan \\
& pada nasabah \end{aligned} & $\begin{array}{l}\text { Strategi WO } \\
\text { Meningkatkan } \\
\text { sosialisai yang lebih } \\
\text { gencar di semua media } \\
\text { untuk meningkatkan } \\
\text { loyalitas nasabah } \\
\text { Menjaga kebersihan } \\
\text { lingkungan }\end{array}$ \\
\hline $\begin{array}{l}\text { Threats } \\
\text { Pemahaman nasabah yang } \\
\text { kurang mengenai kosep } \\
\text { syariah } \\
\text { Semakin banyak kompetitor } \\
\text { baru }\end{array}$ & 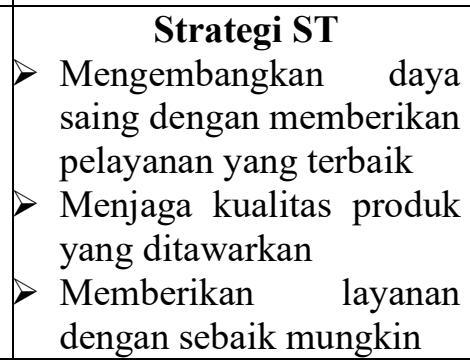 & $\begin{aligned} & \text { Strategi WT } \\
& \text { Meningkatkan daya } \\
& \text { saing produk dengan } \\
& \text { mempertahankan ciri } \\
& \text { khas produk } \\
& \text { Memperkuat layanan } \\
& \text { Islami }\end{aligned}$ \\
\hline
\end{tabular}


Jurnal Ekonomi Syariah Darussalam

Vol I No I Agustus 2020, ISSN: 2745-8407

Analisis SWOT dengan Matrik General Elektronik, sebuah matrik yang menampilkan titk pertemuan hasil skor analisis EFAS dan IFAS yang menunjukkan posisi strategi organisasi untuk kemudian dibandingkan, adapun hasil yang didapat:

Strategi SO (mengoptimalkan kekuatan untuk menangkap peluang)

1. Meningkatkan pengembangan produk

2. Meningkatkan pelayanan pada nasabah

Strategi WO (memanfaatkan peluang untuk meminimalkan kelemahan)

1. Meningkatkan sosialisai yang lebih gencar di semua media untuk meningkatkan loyalitas nasabah

2. Menjaga kebersihan lingkungan

Strategi ST (memanfaatkan kekuatan untuk menghadapi ancaman)

1. Mengembangkan daya saing dengan memberikan pelayanan yang terbaik

2. Menjaga kualitas produk yang ditawarkan

3. Memberikan layanan dengan sebaik mungkin

Strategi WT (meminimalkan kelemahan untuk menghindari ancaman)

1. Meningkatkan daya saing produk dengan mempertahankan ciri khas produk

2. Memperkuat layanan Islami

\section{E. KESIMPULAN}

Berdasarkan hasil penelitian tentang strategi pemasaran Bank Syariah Mandiri dalam meningkatkan penjualan produk pensiun dan bagaimana kekuatan dan kelemahan strategi pemasaran Bank Syariah Mandiri KC Genteng.

1. Strategi pemasaran yang digunakan Bank Syariah Mandiri dalam meningkatkan penjualan produk pensiun yaitu menggunakan strategi pendekatan dan promosi. Para karyawan pensiun lebih efektif menggunakan strategi pendekatan yaitu kunjungan ke rumah nasabah, bagi calon nasabah baru para karyawan harus datang beberapa kali untuk meyakinkan dan memberi rasa percaya terhadap calon nasabah. Pendekatan pada nasabah dapat meningkatkan pertumbuhan jangka panjang Bank Syariah Mandiri dan kepuasan maksimum pelanggan. Setelah melakukan proses pendekatan masuk pada tahap selanjutnya yaitu strategi promosi. Promosi yaitu kegiatan yang bertujuan untuk menyampaikan informasi mengenai produk pensiun kepada nasabah, sehingga produk pensiun tersebut dapat dikenal dan dapat mendorong 
Jurnal Ekonomi Syariah Darussalam

Vol I No I Agustus 2020, ISSN: 2745-8407

para nasabah unuk menggunakannya. Promosi juga sangat berguna untuk memberikan informasi mengenai kelebihan atau keunggulan dari produk pensiun tersebut. Langkah-langkah yang perlu dilakukan marketing untuk dapat mengenalkan produk pensiun dan melayani nasabah mereka dengan baik yaitu membuat nasabah merasa nyaman dan percaya.

2. Penentuan strategi pemasaran harus didasarkan atas analisis lingkungan internal dan eksternal Bank Syariah melalui analisis keunggulan dan kelemahan Bank, serta analisis kesempatan dan ancaman yang dihadapi perusahaan dari lingkungannya. Disamping itu strategi pemasaran yang telah ditetapkan dan dijalankan, harus dinilai kembali, apakah masih sesuai dengan kondisi atau keadaan pada saat itu. Hasil penilaian atau evaluasi ini digunakan sebagai dasar untuk menentukan apakah strategi yang sedang dijalankan perlu diubah, sekaligus digunakan sebagai landasan untuk menyusun atau menentukan strategi yang akan dijalankan dimasa yang akan datang.

Berikut peneliti menguraikan kekuatan, kelemahan, ancaman dan peluang menggunakan analisis SWOT:

1. Kekuatan dari strategi pemasaran Bank Syariah Mandiri KC Genteng adalah kualitas produk yang ditawarkan baik, orientasinya lebih murah dibanding Bank Kompetitor, dilihat dari bagi hasi atau bunganya lebih murah (bunganya efektif $25 \%$, rata-rata $0,6 \%$, dan pertahunnya $12,5 \%$ ).

2. Kelemahan strategi pemasaran Bank Syariah Mandiri yaitu jarak antara nasabah A dan nasabah B saling berjauhan kalah saing dengan kualitas produk Bank lain.

3. Peluang strategi pemasaran Bank Syariah Mandiri yaitu variasi produk yang semakin menarik, memaksimalkan pemasaran, hubungan yang baik dengan nasabah.

4. Ancaman strategi pemasarn bagi para marketing pensiun di Bank Syariah Mandiri yaiitu tingkat persaigan antar Bank, bisnis pensiun adalah semakin banyak kompetitor baru, pemahaman nasabah yang kurang mengenai konsep syariah. 
Jurnal Ekonomi Syariah Darussalam

Vol I No I Agustus 2020, ISSN: 2745-8407

\section{DAFTAR PUSTAKA}

Abdhad, M. K. A. A. 2019. Analisis Strategi Pemasaran pada BRI Syariah Banjarbaru. Jurnal Ilmiah Ekonomi Bisnis. 5 (1).

Anggen Monica. 2012. Marketing is Terrorist. Jakarta: Laskar Aksara.

Arifah, D. N. 2018. Evaluasi Strategi Marketing Door to Door dalam Meningkatkan Loyalitas Anggota di KSPPS Arthamadina Banyuputih Batang. Semarang: UIN Walisongo Semarang.

Arikunto. 2010. Prosedur Penelitian Suatu Pendekatan Praktik. Jakarta: Rineka Cipta.

Assauri Sofjan. 2010. Manajemen Pemasaran. Jakarta: Rajawali Pers.

Badii, Y. A., \& Herawati, R. 2018. Perancangan Sistem Informasi Penjualan dan Bembelian Serta Pengendalian Stok Barang Pada Toko Batik Kusumawardani Solo. Jurnal Go Infotech. 23 (1).

Hartono, H., Hutomo, K., \& Mayangsari, M. 2012. Pengaruh Strategi Pemasaran terhadap Peningkatan Penjualan pada Perusahaan dengan Menetapkan Alumni dan Mahasiswa Universitas Bina Nusantara sebagai Objek Penelitian. Binus Business Review. 3 (2).

Huda nurul, Dkk. 2017. Pemasaran Syariah. Depok: Kencana.

Ismail. 2011. Perbankan Syariah. Jakarta: Kencana.

Wicaksono, R. A. 2017. Analisis Strategi Pemasaran dalam Upaya Meningkatkan Jumlah Pelanggan Perusahaan Daerah Air Minum (PDAM) di Kabupaten Madiun. Universitas Islam Negeri Maulana Malik Ibrahim. Jakarta: PT Raja Grafindo Persada.

Kasmir. 2013. Bank dan Lembaga Keuangan Lainnya. Cetakan ke-13. Jakarta: PT Raja Grafindo Persada.

Kotler Philip. 2004. Marketing Insight From A to Z. Jakarta: Erlangga.

Lidyasari, M. 2018. Strategi Pemasaran dalam Meningkatkan Jumlah Nasabah Tabungan Haji Indonesia pada Bank BRI Syariah Kantor Cabang Sidoarjo. Surabaya: STIE Perbanas Surabaya.

Muhammad. 2011. Manajemen Bank Syariah. Yogyakarta: Unit Penerbit dan Cetakan Sekolah Tinggi Ilmu Manajemen YKPN.

Wicaksono, R. A. 2017. Analisis Strategi Pemasaran dalam Upaya Meningkatkan Jumlah Pelanggan Perusahaan Daerah Air Minum (PDAM) di Kabupaten Madiun. Malang: Universitas Islam Negeri Maulana Malik Ibrahim.

Moleong, Lexy J. 2011. Metodologi Penelitian Kualitatif, Bandung: PT Remaja Rosdakarya.

Nisak, Z. 2014. Analisis SWOT untuk Menentukan Strategi Kompetitif. Jurnal EKBIS. Fakultas Ekonomi: Universitas Islam Lamongan.

Sabariah Etika. 2016. Manajemen Strategis. Yogyakarta: Pustaka Pelajar.

Sari, S. W. P. 2018. Strategi Pemasaran BMT Al Hikmah dalam Meningkatkan Hasil Usaha. Semarang: UIN Walisongo Semarang. 